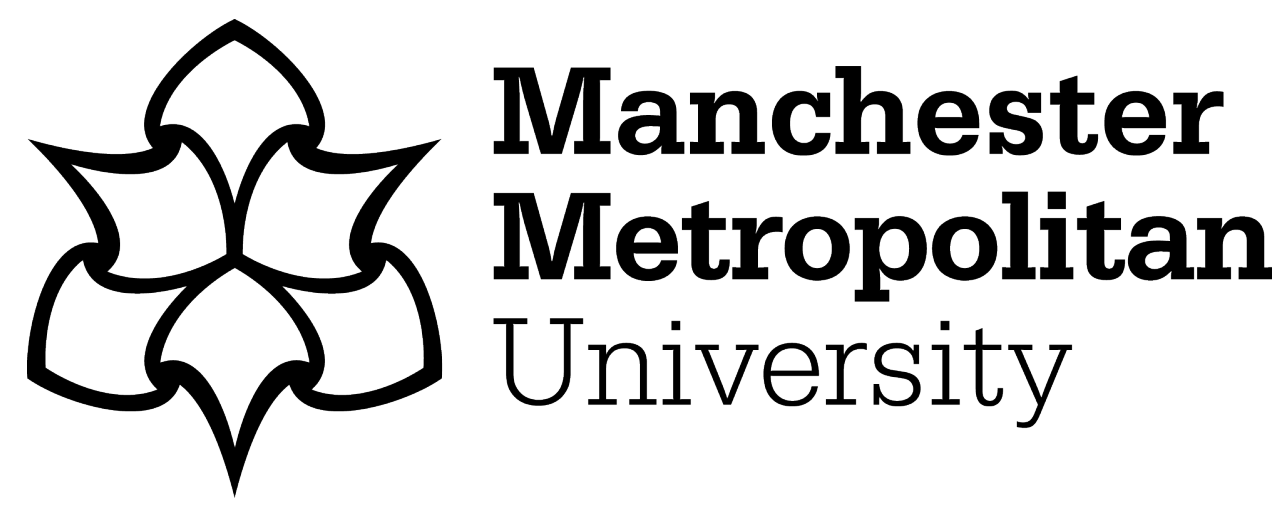

de Almeida, Arlete S, Vieira, Ima CG, Moura, Nárgila and Lees, Alexander C ORCID logoORCID: https://orcid.org/0000-0001-7603-9081 (2020) Heterogeneity of tree diversity and carbon stocks in Amazonian oil palm landscapes. Plant Ecology \& Diversity, 13 (1). pp. 105-113. ISSN 1755-0874

Downloaded from: https://e-space.mmu.ac.uk/625262/

Version: Accepted Version

Publisher: Informa UK Limited

DOI: https://doi.org/10.1080/17550874.2019.1710616

Please cite the published version 


\title{
Heterogeneity of tree diversity and carbon stocks in Amazonian oil palm landscapes
}

\author{
Arlete S. de Almeida ${ }^{1}$, Ima C. G. Vieira ${ }^{1 \star}$, Nárgila Moura ${ }^{1}$ and Alexander C. Lees ${ }^{2,3}$ \\ ${ }^{1}$ Museu Paraense Emílio Goeldi, Belém, PA, Brasil; '2School of Science and the Environment, Manchester \\ Metropolitan University, Manchester, U.K.; ${ }^{3}$ Cornell Lab of Ornithology, Cornell University, Ithaca, NY, USA \\ ${ }^{*}$ Corresponding author. Email: ima@museu-goeldi.br
}

\begin{abstract}
Background: Quantitative effects of large-scale oil palm expansion in the Neotropics on biodiversity and carbon stocks are still poorly documented.
\end{abstract}

Aims: We evaluated differences in tree species composition and richness, and above-ground carbon stocks among dominant land cover types in Pará state, Brazil.

Methods: We quantified tree species composition and richness and above-ground carbon stock in stands in remnant primary rain forest, young secondary forest, oil palm plantation and pastures.

Results: We sampled 5,696 trees with a $\mathrm{DBH} \geq 2 \mathrm{~cm}$, of 413 species in 68 families, of which 381 species were recorded in primary forest fragments. We found significant differences in species richness and carbon stock among the four land cover classes. Carbon stocks in remnant primary forest were typically over $190 \mathrm{Mg} \mathrm{ha}^{-1}$, while those in other land cover types were typically less than $60 \mathrm{Mg} \mathrm{ha}^{-1}$.

Conclusion: Oil palm plantations have a species-poor tree community given active management; old plantations have a standing carbon stock which is comparable to that of secondary forest and far greater than that of pastures. Private forest reserves within oil palm company holdings play an important role in preserving primary forest tree diversity in human-modified landscapes in Amazonia.

Keywords: land cover; plantations; biofuel; community composition; arboreal biomass Introduction

Driven by increasing demand for food and biofuel, the expansion in the acreage of oil palm (Elaeis guineensis Jacq.) has become a major driver of loss of primary forest habitats globally (Fitzherbert et al. 2008). Oil palm is the most important vegetable oil in terms of worldwide quantity of production and now accounts for about $10 \%$ of the world's permaculture area (Pirker et al. 2016). Forest conversion to oil palm plantation has most acutely impacted Indonesia and Malaysia. For example, an analysis of FAO data has found that, during the period from 1990 to 2005, more than half of oil palm expansion in Malaysia occurred at the expense of forests (Koh and Wilcove 2008). Recent decades have seen expansion of oil palm plantations in Africa and South America (Butler and Laurence 2009). In particular, the Amazon basin has been earmarked as the next major frontier for expansion (Reis and Guzmán 2015). The state of Pará is currently responsible for $95 \%$ of the palm oil production in Brazil. 
The regional agro-ecological zoning exercise for oil palm (ZAE-Dendê) has identified existing deforested and degraded areas as targets for oil palm planting (Brasil 2010). The official Brazilian program for oil palm expansion (PPSOP) has been justified, in addition to its catalysing regional development, by evoking that perennial crops such as oil palm may help restore soil quality, protect against soil erosion and contribute to carbon sequestration (Homma et al. 2000). However, an increase in the oil palm acreage has generated concerns that expansion may come at the expense of land for existing agricultural production, leading to opening up more areas for agriculture and thus indirectly resulting in deforestation (Butler and Laurence 2009). Ninety per cent of this expansion in oil palm production occurred on former pasture land rather than forest and direct conversion of primary forest to oil palm declined from $4 \%$ from 2006-2010, to less than 1\% between 2010-2014 across 50,000 km2 of eastern Pará (Benami et al. 2018).

There is a historical landscape degradation associated with oil palm expansion in the eastern Amazon region (Almeida et al. 2020). The impacts of this expanding oil palm acreage on Amazonian biodiversity have been little studied. However, it is known that plantations offer poor habitats for birds (Lees et al. 2015) and mammals (Mendes-Oliveira et al. 2017) and reduce the integrity of aquatic ecosystems (Cunha et al. 2015). Before large-scale planting of oil palm is undertaken solely on the basis of statements that it is a relatively green source of energy with low environmental impacts, a thorough assessment of environmental impacts is required (Yusoff 2006; Basiron 2007; Tan et al. 2009; Moni and Sulaiman 2013). In Brazil, there has been pressure since 2005 by diverse stakeholders (including politicians and producers) to legally declare oil palm plantations a 'low impact' form of land use. If such a definition were accepted, it could greenlight oil palm planting instead of restoring illegally deforested land parcels with native vegetation which land-owners are currently required to do (Lees and Vieira 2013). The legally mandated maintenance of native forests on private landholdings (so-called 'legal reserves' amounting to $80 \%$ of a property in most parts of Amazonia) is essential for maintaining a multitude of ecosystem services (incl. carbon sequestration) and conserving biodiversity. Some of the largest native forest remnants in eastern Pará are found on private properties, but the value of these forests is undermined by their being subject to disturbance from fire and logging (Berenguer et al. 2014; Moura et al. 2014).

The replacement of forests by crop-pasture matrices has predictably severe consequences for biodiversity (Peres et al. 2010) and farm management decisions and choices of land use influence the conservation of adjacent forest remnants. The quantification of the structure and diversity of tree species in different land cover types is important since they may provide resources and habitat for several forestassociated species and are thus been a vital instrument in assessing forest conservation status and a measure of the sustainability. The conversion of primary forest to oil palm has been reported to result in a reduction of carbon stock by over $50 \%$, with the above-ground biomass loss contributing to $89 \%$ of the overall carbon loss (Morel et al. 2011). However, planting oil palm on abandoned pastures increases carbon sequestration and storage relative to those in pasture. Our objective was to provide an evidencebase for conservation/legal designation for restoration priorities on the basis of the relative values/impacts of land cover types. We quantified tree species richness and composition and above-ground carbon stock in four dominant land cover types: remnant primary forest, young secondary forest, oil palm plantation and pasture land. We assessed biodiversity and standing carbon stock values, relative to primary forest, of production areas (Peres et al. 2010), secondary forests (Almeida and Vieira 2001; Ferreira et al. 2018), and primary forest remnants, most of them degraded by fire and logging (Barlow et al. 2016).

Understanding how much native woody vegetation persists in production areas, even in the face of active attempts at suppression, is important as it is likely to facilitate persistence of wildlife in these habitats (Gilroy et al. 2015). 


\section{Materials and methods}

\section{Study area}

The study was conducted in three areas (Figure 1) that encompass parts of the municipalities of Moju, Acará and Tailândia, over 2,588 km2 in north-east Pará state (hereafter Moju) which includes the landholdings of three different oil palm producing companies. The three areas differ somewhat in their history of use, land-tenure strategies and time since the start of production. All these landholdings retain varyingly sized patches of primary forest in a complex landscape with high connectivity to the surrounding skeletal forest matrix.

Figure 1. Primary forest, secondary forest, oil palm plantation and pasture were sampled in three sampling areas (1, Moju; 2, Tailândia; 3, Acará) in Pará state, Brazil (a). Background image (Landsat 8) shows land cover in 2013. The close-up of Area 2 showing survey localities (b); and sampling design (c).
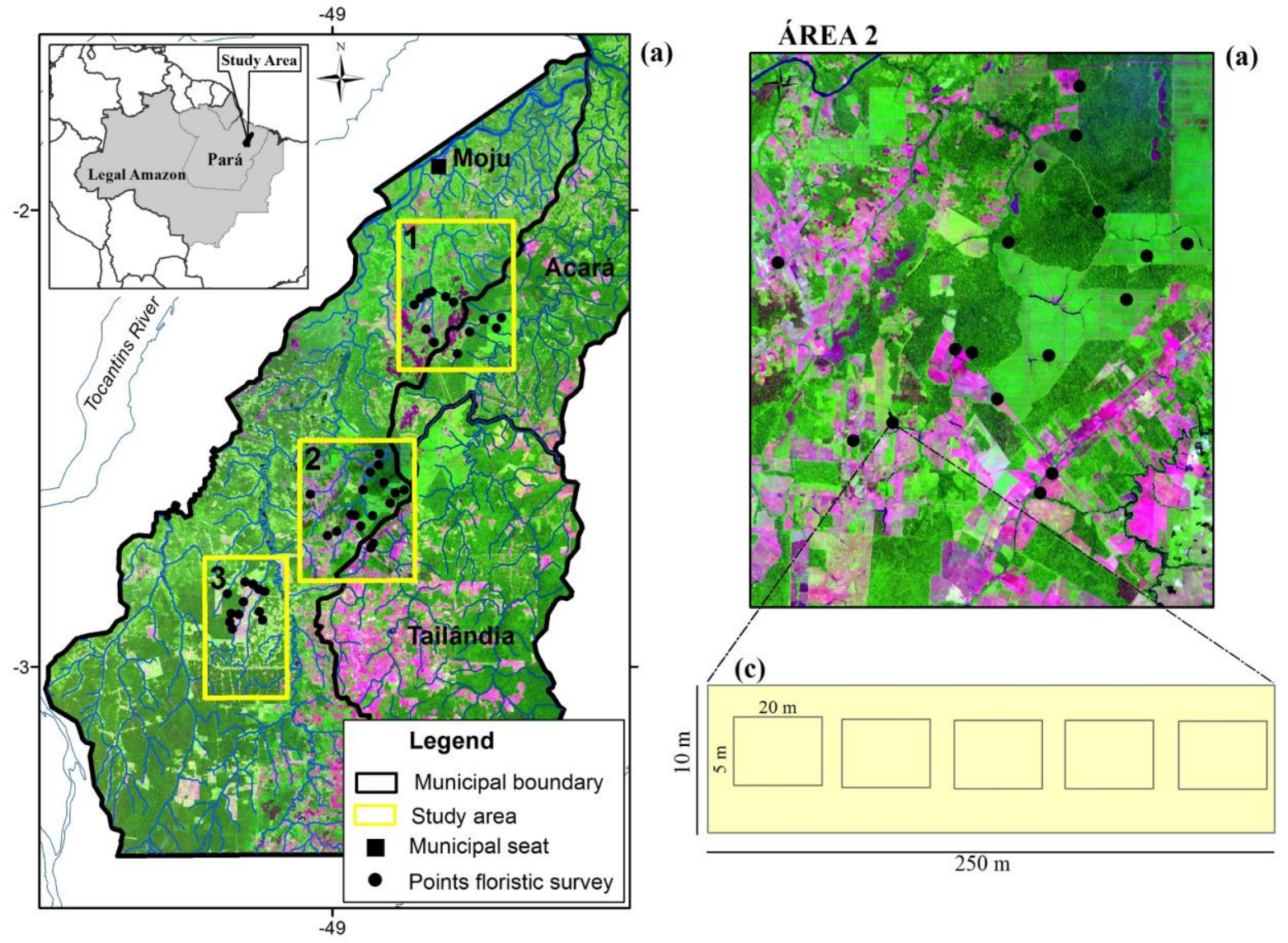

There are four dominant land cover types in the area. Primary forest (PF) comprises dense tropical rain forest and more open rain forest of 30-40 m tall canopy, with occasional emergent (Putz and Redford 2010). Some of these forest remnants have been subject to recent, often intense human exploitation with selective logging and accompanying logging roads and log landings resulting in forest degradation and at least occasional wildfire events. Secondary forests (SF) are successional forests that follow land abandonment (Putz and Redford 2010), which in Amazonia includes typically slash-and-burn systems or degraded cattle pastures. Oil palm (OP) plantations have mean canopy height in mature plantations of 8 $\mathrm{m}$ and a density of stems 136-160 ha-1. Cattle pastures (Past) are a dominant production land cover type in southern Amazonia as well as in our study area. 
Soils are dystrophic yellow latosols (EMBRAPA 2009) and forests are naturally dense lowland evergreen tropical forests growing on low plateau tablelands that are not inundated periodically, as well as on fluvial terraces and floodplains. The regional climate is hot and humid with an annual mean temperature of $26.9^{\circ} \mathrm{C}$. Precipitation varies between 2,000 and $3,000 \mathrm{~mm}$ year -1 , with most rainfall occurring from January to June. The local population consists mainly of smallholders, rural workers, riverine and quilombola (traditional communities of Afro-Brazilian descent) communities. In recent years, the region has undergone a strong expansion of productive activities, focusing on the service sector and agriculture (IBGE 2010) and is currently the centre of a large-scale oil palm expansion in Brazil.

Floristic and structural inventories

Study plots of 2,500 m2 in size were established in PF, SF, OP and Past to collect floristic and structural data. We employed a stratified random sampling design, where plots were distributed across the study region in proportion to the per cent cover of land cover types to increase the likelihood of capturing important internal heterogeneities within land cover types. Vegetation data were gathered from 31 plots, comprising: 17 in PF, four in SF of varying ages (5-20-year-old), seven in variable-aged OP (12-25-yearold) and three in cattle pastures (5-22-year-old). All live trees and palms with a diameter at breast height $(\mathrm{DBH})>10 \mathrm{~cm}$ were measured in $10 \mathrm{~m} \times 250 \mathrm{~m}$ plots and smaller individuals $\mathrm{DBH}>2<10 \mathrm{~cm}$ were sampled in five subplots of $5 \mathrm{~m} \times 20 \mathrm{~m}$ within each plot, following the methodology of Gardner et al. (2013). Tree heights were measured from the base of the tree to the highest point from the ground (parallel to the main trunk) using a 5-m ranging pole for shorter trees and visual estimation for taller ones. All plots were separated by at least $1,500 \mathrm{~m}$ from each other to minimise spatial dependence and the plots were located at least $100 \mathrm{~m}$ from the nearest border with another habitat type to avoid edge effects.

Trees were identified to species level in the field by expert botanists; herbarium samples were collected for identification when field identification was deemed impossible. Such samples were deposited at the Herbário João Murça Pires, Museu Paraense Emílio Goeldi, Belém. Species were assigned to families based on the APG IV system (APG IV 2016).

\section{Data analysis}

To compare species accumulation curves among different land cover types, we constructed samplebased rarefaction curves, using the Mau Tao estimate (Colwell et al. 2012) with 95\% confidence intervals using the R package 'vegan' v. 2.5-4 (Oksanen et al. 2019).

The data recorded were quantitatively analysed for frequency, density and dominance and the relative values of these parameters were calculated and summed in an Importance Value Index (IVI) (Cottam and Curtis (1956) using Mata Nativa 2 (CIENTEC 2006) as follows: IVli = RFi + RDi + RBAi where, IVli is the Importance Value Index of species $\mathrm{i}$; RFi is the relative frequency of species $\mathrm{i}$; RDi is the relative density of species $\mathrm{i}$ and RBAi is the relative basal area of species $\mathrm{i}$. Above-ground biomass (Mg ha-1) was estimated for each land cover type using allometric equations for individuals with $\mathrm{DBH} \geq 2 \mathrm{~cm}$ (Table 1). For species recorded in PF, SF and Past, biomass was calculated using an equation adjusted for tropical forests (Chave et al. 2005). For the genus Cecropia, we used an equation developed by Nelson et al. (1999), using $\mathrm{DBH}(\mathrm{cm})$ and stem height $(\mathrm{m})$ as variables. The biomass of $\mathrm{E}$. guineensis was estimated using an equation from Corley and Tinker (2003) that considers the total height (m) and DBH $\geq 1 \mathrm{~cm}$. Values of wood density were extracted from Chave et al. (2009) and Zanne et al. (2009). The carbon stock was estimated for each land-use using the above-ground biomass estimates, assuming that total stem carbon represented $50 \%$ of above-ground biomass, following Berenguer et al. (2014). 
Table 1. Equations used to estimate the biomass for all species with a $\mathrm{DBH} \geq 2 \mathrm{~cm}$, for the genus Cecropia and for the species Elaeis guineensis

\begin{tabular}{ccc}
\hline References & Category/species & Equation \\
\hline $\begin{array}{c}\text { Chave et al. } \\
2005\end{array}$ & $\mathrm{DBH} \geq 2 \mathrm{~cm}$ & $(A G B)_{E S T}=0.0509 * \rho D^{2} H$ \\
$\begin{array}{c}\text { Nelson et al. } \\
1999\end{array}$ & $\begin{array}{c}\text { Cecropia sp. } \\
\mathrm{DBH} \geq 2 \mathrm{~cm}\end{array}$ & $\mathrm{DW}=\mathrm{EXP}(2.5118+2.4257 \times \mathrm{Ln}(\mathrm{DBH}))$ \\
& & \\
Corley and & Elaeis guineensis & $B t=\pi \times(r \times \mathrm{Z})^{2} \times 100 \times h \times \rho$ \\
Tinker 2003 & $\mathrm{DBH} \geq 1 \mathrm{~cm}$ & $\rho=\frac{I d \times 0.0076+0.083}{1000}$ \\
& & \\
\hline
\end{tabular}

$A G B$, estimated biomass; $\rho$, wood density; $D W$, calculated biomass for the genus Cecropia; $B t$, biomass of the trunk (stipe) of Elaeis guineensis; $r$, trunk radius; $Z$, diameter of the base, estimated in $0.777 ; h$, total height; $\rho$, trunk density. 
Landscape context and tree diversity

As the data were not normally distributed (Shapiro-Wilk test; $W=0.71, P<0.05$ ) we used the nonparametric Kruskal-Wallis test with 95\% confidence intervals followed by the Dunn's test to test for significant pair-wise differences between land cover types for species richness and carbon stocks. To test for the effect of landscape configuration on tree species diversity and carbon stocks we visualised the mean distance from each plot to the nearest primary forest edge. All fieldwork took place on private properties and landowners were visited prior to fieldwork to introduce the project and secure permissions for surveys.

\section{Results}

We recorded 5,696 individuals with a $\mathrm{DBH} \geq 2 \mathrm{~cm}$, of 413 species in 68 families, of which 381 species were recorded in PF (303 exclusive PF species). Of these 381 species, 93 were recorded in other land cover types, 77 in SF, 13 in Past and four in OP.

Floristic composition of the tree communities

The highest mean richness of tree species and families was recorded in PF, meanwhile OP had the lowest values (Table 2). Species accumulation curves indicated an asymptotic pattern in PF and OP, while for SF and Past the curves showed a tendency of continued increase, indicating insufficient sampling effort (Figure S1).

Table 2. Summary table of taxonomic richness and aboveground biomass carbon stocks in primary forest, secondary forest, oil palm plantation and pasture, Moju region, Pará, Brazil. PF, primary forest; SF, secondary forests; OP, oil palm plantation; and PAST, cattle pasture.

$\mathrm{DBH} \geq 10 \mathrm{~cm}$

\begin{tabular}{|c|c|c|c|c|c|c|c|}
\hline $\begin{array}{l}\text { Land cover } \\
\text { type }\end{array}$ & Plots & $\begin{array}{c}\text { Sample } \\
\text { area (ha) }\end{array}$ & Individual & Species & Family & $\begin{array}{l}\text { Biomass } \\
\left(\mathrm{Mg} \mathrm{ha}^{-1}\right)\end{array}$ & $\begin{array}{c}\text { Carbon } \\
\text { stock } \\
\left(\mathrm{Mg} \mathrm{ha}^{-1}\right)\end{array}$ \\
\hline PF & 17 & 4.25 & 2173 & 273 & 48 & 306.75 & 153.67 \\
\hline SF & 4 & 1.00 & 359 & 54 & 25 & 28.12 & 14.06 \\
\hline OP & 7 & 1.75 & 363 & 2 & 2 & 58.86 & 29.43 \\
\hline \multicolumn{8}{|c|}{$>2 \mathrm{~cm} \mathrm{DBH}<10 \mathrm{~cm}$} \\
\hline PF & 85 & 0.85 & 2135 & 283 & 53 & 81.61 & 40.80 \\
\hline SF & 20 & 0.20 & 612 & 87 & 30 & 92.49 & 46.24 \\
\hline $\mathrm{OP}$ & 5 & 0.05 & 13 & 3 & 3 & 0.52 & 0.26 \\
\hline PAST & 10 & 0.10 & 41 & 15 & 10 & 6.10 & 3.05 \\
\hline
\end{tabular}

At the species level, the taxonomic composition of the land cover types showed major differences (Table 3). The upper strata $(\mathrm{DBH}>10 \mathrm{~cm}$ ) of PF were dominated by Eschweilera coriacea $(\mathrm{IVI}=21.5)$ and Lecythis idatimon (IVI = 14.2) and Lecythidaceae and Fabaceae were the most common tree families. Fabaceae was also the dominant family in SF in the canopy and sub-canopy strata. Small trees such as Rinorea guianenis and R. flavescens (Violaceae) were common in the lower strata of PF while Poecilanthe effusa (Fabaceae) dominated in SF. In OP, trees were essentially represented by the planted E. guineensis and four shade tree species. In Past, we did not record any trees with a DBH $>10 \mathrm{~cm}$. 
Table 3. The top tree species ordered by their Importance Value Index (IVI) values in PF, primary forest; SF, secondary forest; OP, Oil palm plantations; and PAST, pasture, Moju region, Pará state, Brazil.

\begin{tabular}{|c|c|c|c|}
\hline \multicolumn{4}{|c|}{$\mathrm{DBH}(>10 \mathrm{~cm})$} \\
\hline Species & Family & IVI & LAND COVER \\
\hline Eschweilera coriacea (DC.) S.A.Mori & Lecythidaceae & 21.5 & \\
\hline Lecythis idatimon Aubl. & Lecythidaceae & 14.23 & \\
\hline Rinorea guianensis Aubl. & Violaceae & 11.77 & \\
\hline Vouacapoua americana Aubl. & Fabaceae & 10.83 & \\
\hline Eschweilera grandiflora (Aubl.) Sandwith & Lecythidaceae & 8.83 & PF \\
\hline Cecropia sciadophylla Mart. & Urticaceae & 6.53 & \\
\hline Sterculia pruriens (Aubl.) K.Schum. & Malvaceae & 5.60 & \\
\hline Inga alba (SW.) Willd. & Fabaceae & 5.04 & \\
\hline Inga thibaudiana DC. & Fabaceae & 5.02 & \\
\hline Licania canescens Benoist & Chrysobalanaceae & 4.29 & \\
\hline Inga alba (SW.) Willd. & Fabaceae & 34.79 & \\
\hline Cecropia palmata Willd. & Urticaceae & 16.79 & \\
\hline Inga rubiginosa (Rich.) DC. & Fabaceae & 15.06 & \\
\hline Annona exsucca DC. & Annonaceae & 14.76 & SF \\
\hline Vismia guianensis (Aubl.) Choisy & Hypericaceae & 13.84 & \\
\hline Stryphnodendron guianense (Aubl.) Benth. & Fabaceae & 13.03 & \\
\hline Eriotheca globosa (Aubl.) A.Robyns & Malvaceae & 12.92 & \\
\hline $\begin{array}{l}\text { Schizolobium parahyba var. amazonicum } \\
\text { (HuberexDucke) Barneby }\end{array}$ & Fabaceae & 12.63 & \\
\hline Nectandra cuspidata Nees\&Mart. & Lauraceae & 12.13 & \\
\hline Cordia scabrifolia A.DC. & Boraginaceae & 9.98 & \\
\hline Elaeis guineenses Jacq. & Arecaceae & 276.66 & \\
\hline Cecropia distachya Huber & Urticaceae & 13.77 & OP \\
\hline \multicolumn{4}{|c|}{$\mathrm{DBH}(2 \mathrm{~cm}<10 \mathrm{~cm})$} \\
\hline Rinorea guianensis Aubl. & Violaceae & 16.50 & \\
\hline Rinorea flavescens (Aubl.) Kuntze & Violaceae & 11.13 & \\
\hline Eschweilera coriacea (DC.) S.A.Mori & Lecythidaceae & 9.43 & \\
\hline $\begin{array}{l}\text { Dodecastigma integrifolium (Lanj.) Lanj. \& } \\
\text { Sandwith }\end{array}$ & Euphorbiaceae & 8.45 & \\
\hline Protium trifoliolatum Engl. & Burseraceae & 6.55 & PF \\
\hline Vouacapoua americana Aubl. & Fabaceae & 6.06 & \\
\hline Sagotia racemosa Baill. & Euphorbiaceae & 5.88 & \\
\hline Lecythis idatimon Aubl. & Lecythidaceae & 5.50 & \\
\hline Pouteria decorticans T.D.Penn & $\underline{\text { Sapotaceae }}$ & 5.03 & \\
\hline Fusaea longifólia (Aubl.) Saff. & Annonaceae & 4.72 & \\
\hline Poecilanthe effusa (Huber) Ducke & Fabaceae & 22,84 & \\
\hline Ocotea glomerata (Nees)Mez & Lauraceae & 19,81 & \\
\hline Banara guianensis Aubl. & Salicaceae & 19,44 & \\
\hline Vismia guianensis (Aubl.) Choisy & Hypericaceae & 14,41 & SF \\
\hline Cecropia palmata Willd. & Urticaceae & 14,31 & \\
\hline Annona exsucca DC. & Annonaceae & 13,66 & \\
\hline Inga alba (SW.) Willd. & Fabaceae & 12,38 & \\
\hline Cupania scrobiculata Rich. & Sapindaceae & 8,86 & \\
\hline Cordia exaltata Lam. & Boraginaceae & 8,22 & \\
\hline Byrsonima crispa A.Juss. & Malpighiaceae & 6,76 & \\
\hline Cecropia palmata Willd. & Urticaceae & 192.90 & \\
\hline Inga thibaudiana DC. & Fabaceae & 37.46 & OP \\
\hline Banara guianensis Aubl. & Salicaceae & 37.46 & \\
\hline Vismia guianensis (Aubl.) Choisy & Hypericaceae & 55,52 & \\
\hline Banara guianensis Aubl. & Salicaceae & 34,62 & \\
\hline Guatteria poeppigiana Mart. & Annonaceae & 28,75 & \\
\hline
\end{tabular}


Inga alba (SW.) Willd.

Inga thibaudiana DC.

Cordia scabrifolia A.DC.

Tapirira guianensis Aubl.

Eschweilera grandiflora (Aubl.) Sandwith

Lacunaria crenata (Tul.) A.C.Sm.

Xylopia nítida Dunal
Fabaceae $\quad 24,90$

Fabaceae 21,32

Boraginaceae $\quad 16,70$

Anacardiaceae $\quad 16,64$

Lecythidaceae $\quad 15,56$

Quiinaceae $\quad 15,15$

Annonaceae $\quad 14,56$
PAST

Species richness and carbon stock

We found significant differences among land cover types for both species richness $(H=41.5, d f=3, P<$ 0.05 Figure 2(a)) and carbon stocks $(\mathrm{H}=41.1, \mathrm{df}=3, \mathrm{P}<0.05$, Figure 2(b)), with $\mathrm{PF}$ having the highest mean \pm SE species richness $(93 \pm 1.9)$ followed by SF $(44 \pm 1.2)$ and Past $(7 \pm 4)$. Between-group differences were significantly different between PF and Past and PF and OP for both species richness and carbon stock. There were significant differences in the composition of tree species between PF and the other land cover types $(F=12.901, P<0.001$; Figure 3$)$. Species accumulation curves (Figure $S 1)$ only approached asymptotes in OP, although sample sizes for Past with enough woody biomass were low.

Figure 2. Box plots of species richness (a) and carbon stock (b) in primary forest (PF), secondary forest (SF), oil palm (OP), and cattle pasture (Past) in the Moju region, Pará, Brazil.
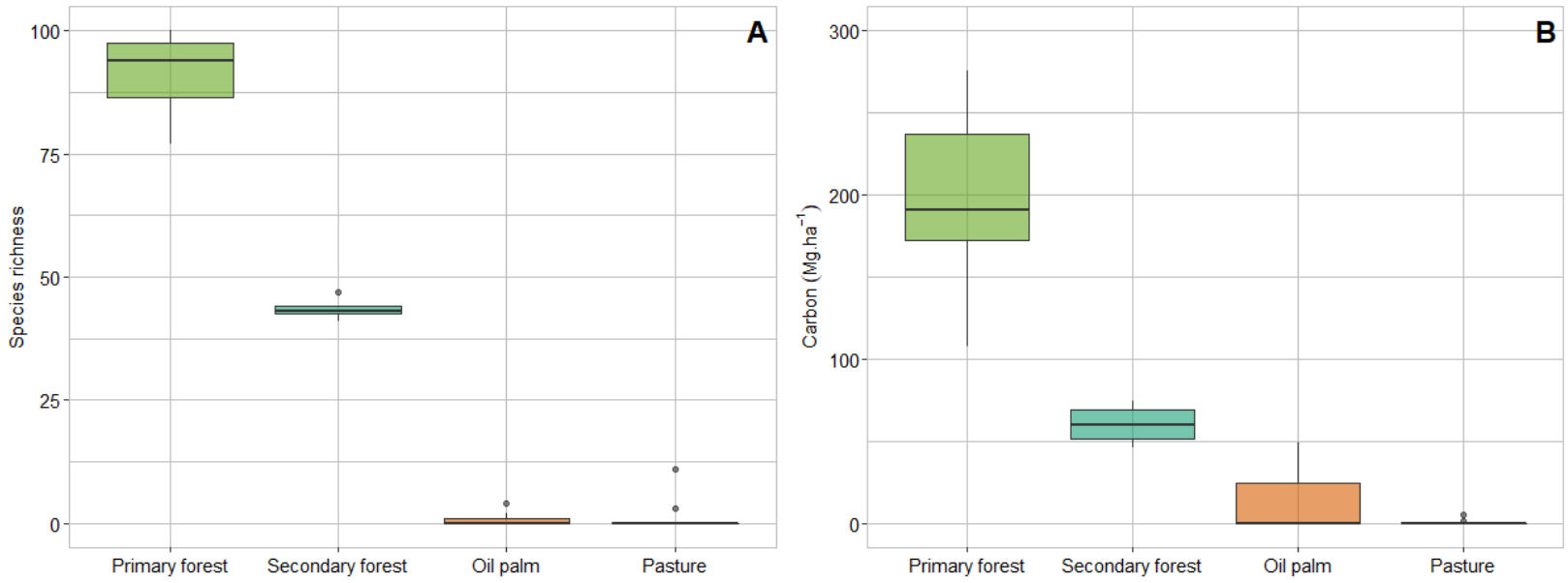

Figure 3. MDS plots of tree community composition between land-cover classes: primary forest, secondary forest, oil palm and cattle pasture in the Moju region, Pará, Brazil, showing strong clustering of 
primary forest and secondary forest stands whilst remaining land covers are more dissimilar.

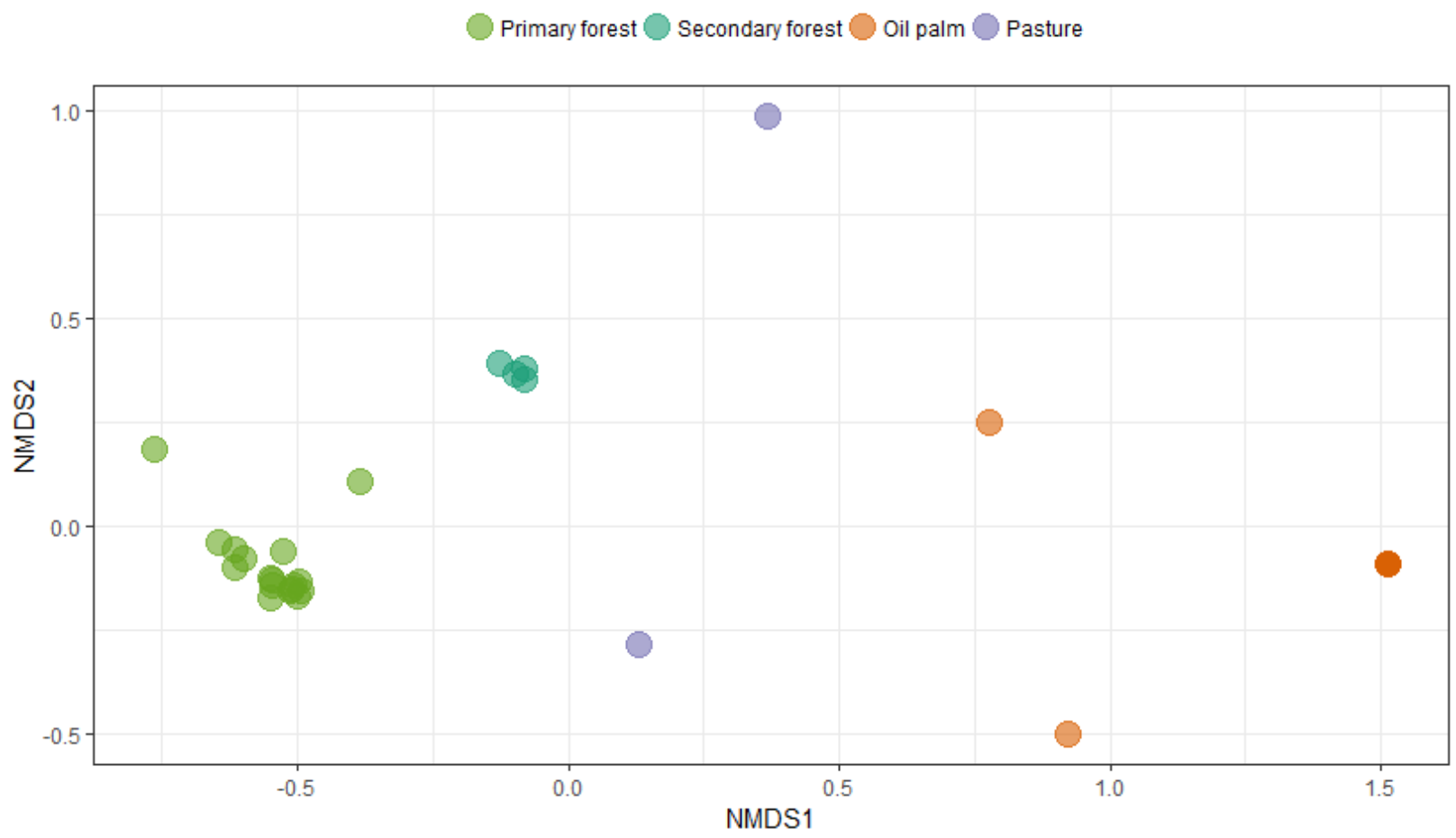

The assemblages were rather distinct in their composition, especially PF; there was some compositional overlap between OP and Past. Secondary forest had its own discrete assemblage composition and its species richness was intermediate between that of PF and OP and Past (Figure 4(a)). We did not find evidence for strong effects of distance from the primary forest edges in mediating either carbon stock or species richness for SF, OP and Past (Figure 4(b)); note that none of the sampled secondary forests were $>700 \mathrm{~m}$ from the nearest PF.

Figure 4. Species richness (a) and carbon stock (b) of land cover types in the Moju region, Pará, Brazil demonstrating little variation in response to distance to the nearest primary forest edge.
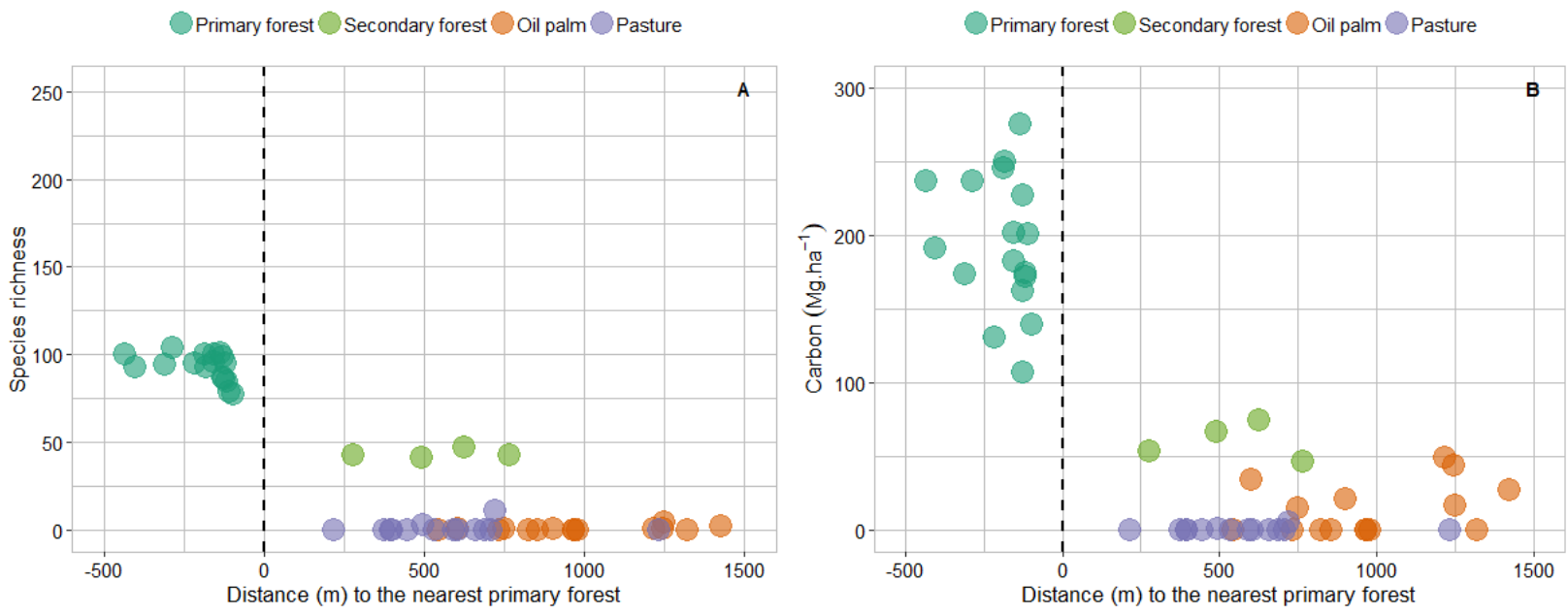


\section{Discussion}

Our study provides, for the first time, real data about tree diversity in Neotropical oil palm plantations. The results confirmed that these plantations have very low species richness, which is related to management to suppress regeneration to avoid competition for water, light and nutrients, by other woody species. Management was probably responsible for cancelling out any potential effect on species richness of proximity to primary forest. Despite a pervasive history of disturbance, remnant PF within OP plantations in the Moju region still retains relatively high tree diversity and biomass carbon, and support a significant proportion of the species assemblage of continuous forest. Lecythidaceae and Fabaceae were the most abundant families in these forests, and are almost invariably present in native forests in the Amazon basin (Ter Steege et al. 2000). Secondary forests are typically characterised by an abundance of fastgrowing taxa of early successional stages and even 70-year-old secondary forests in eastern Amazonia have a conspicuously different taxonomic composition from that of primary forests of comparable stature (Vieira et al. 2003; Vieira 2019). The ecological and ecosystem service values of secondary forests are lower in comparison with those of primary forests, however secondary forests are important for conservation in fragmented oil palm dominated landscapes as the carbon stocks and biodiversity in older secondary forests approach $80 \%$ of that found in undisturbed primary forests (Lennox et al. 2018).

The role of secondary forests, and their potential to contribute to restoring soil functions, carbon sequestration and biodiversity conservation, especially in heavily impacted regions is considered important (Chazdon et al. 2009; Poorter et al. 2016). Secondary forests are rarer in the landscape than disturbed primary forests and pastures in the Moju region, and almost all are quite young and often return to production (slash-and-burn) after few years of fallowing. They have thus not been afforded the time to acquire much biodiversity or biomass, reflected in their hosting of on average less than half of the species associated with primary forests.

The predictable loss of tree diversity and above-ground carbon stocks with increasing land use intensity (conversion to plantation and agricultural) matches the pattern found in various other studies (e.g. Almeida and Vieira 2001; Berenguer et al. 2014). These non-forest land cover types retained no more than $30 \mathrm{Mg}$ ha-1 carbon stock in our study, well below that found in primary forest (194.5 Mg ha-1) (Table 2). This result underscores the message that oil palm is no substitute, either in terms of biodiversity conservation or carbon sequestration and storage, for native vegetation and protection areas and legal reserves should not be planted with oil palm (Lees and Vieira 2013). If legal reserves were formed by intact primary forest, covering $80 \%$ of the rural properties of Moju region it should allow the preservation of most of biodiversity and the maintenance of important ecosystem functions.

The role of oil palm in sequestering and storing carbon during its lifetime (25-30 years) is similar to that recorded in young secondary forests. Our estimated above-ground carbon stock of $33 \mathrm{Mg}$ ha-1 at 12 years is comparable to the $30 \mathrm{Mg}$ ha-1 found by Filho (2012) for an 11-year-old plantation in north-east Pará. Palm trees reaching around 25-30 years of age are cut down, zeroing the standing carbon stock. By comparison, late-successional secondary forests in the region can reach $70 \mathrm{Mg}$ ha- 1 of carbon after 70 years (Almeida and Vieira 2001). Our carbon stock values in secondary forests in the current study are conservative estimates limited by the relative scarcity of old secondary forests and consequent low sample sizes.

Most areas identified as suitable for oil palm are located along the Amazonian Arc of Deforestation in southern Amazonia where forest loss and fragmentation are ongoing and potentially increasing after a recent decrease (Lees and Peres 2006; Freitas et al. 2018). Previous work has shown that oil palm expansion in Amazonia had occurred mostly at the expense of secondary forests, albeit affecting some areas of primary forest, thus oil palm expansion here has resulted so far in less loss of tropical forest than elsewhere in the tropics (Benami et al. 2018). Secondary forests have received legal protection in recent 
years in the state of Pará after establishing quantitative criteria that deemed when early-successional secondary forests should be preserved in rural properties (Vieira et al. 2014). Avoiding any conversion of primary or secondary forest in advanced stage of succession into plantations and restricting expansion of new plantations onto land with low carbon stocks ought to result in carbon-neutral production (Agus et al. 2013). Maintaining biodiversity and conserving carbon stocks almost always incur a substantial financial opportunity cost but the environmental and land use value trade-offs associated with oil-palm expansion can be potentially handled by using adequately planned and spatially explicit development strategies (Butler and Laurence 2009; Gilroy et al. 2015). Future work in Amazonia should explore displacement of smallholder agriculture resulting in further forest loss or negative implications for local food security.

\section{Conclusions}

We demonstrate that oil palm plantations support very low tree diversity and modest carbon stocks, the latter comparable to that of young secondary forests. Conversely, remnant primary forest in the legal reserve portion of plantations maintains substantial tree diversity and associated biota and carbon stocks. Regional development plans need to consider the conflicting interests of different social actors, institutions and companies, monitoring the health of primary and secondary forests to see that environmental quality is not jeopardised by oil palm or other large-scale monocultures. Integration needs to occur across development policy, company strategies and with local farmers and is a fundamental criterion for sustainable expansion production of oil palm in Amazonia. Given the role that diverse plant communities have in supporting species in other groups, future work should focus on the diversity of plant communities in understorey vegetation. Future research and policy discussions also need to focus on a broader view of environmental management of oil palm plantations integrating an approach of valuating ecosystem services and biodiversity conservation in oil palm landscapes that can provide a basis for sustainable land use policies in the Amazon region.

\section{Acknowledgements}

We thank the Post-graduate Programme in Environmental Science, Federal University of Pará for the Ph.D. opportunity for the first author. I.C.G.V. acknowledges CNPq productivity grant no. 308778/2017-0. We thank Carlos Alberto Silva, Nelson Rosa, Carlos Alberto Silva Junior, Rodolfo Rayol for plant identification and support in the fieldwork; the oil palm companies Agropalma, Biopalma, Belém Bioenergia and the Museu Paraense Emilio Goeldi for institutional support.

\section{References}

Agus F, Henson IE, Sahardjo BH, Harris Van Noordwijk M, Killeen TJ. 2013. Review of emission factors for assessment of $\mathrm{CO} 2$ emission from land use change to oil palm in Southeast Asia. In Killeen TJ, Goon J, editors. Reports from the Technical Panels of the Second RSPO GHG Working Group. Kuala Lumpur: Rou on Sust Palm Oil; p. 7-27.

Almeida AS, Vieira ICG. 2001. Padrões florísticos e estruturais de uma cronossequência de florestas no munícipio de São Francisco do Pará, região Bragantina, Pará. Boletim do Museu Paraense Emílio Goeldi, Série Botânica. 17(1):209-240.

Almeida AS, Vieira ICG, Ferraz, S.F. 2020. Long-term assessment of oil palm expansion and landscape change in the eastern Brazilian Amazon. Land Use Policy 90,104321. https://doi.org/10.1016/j.landusepol.2019.104321.

Barlow, J, Lennox, GD, Ferreira, J, Berenguer, E, Lees, AC, MacNally R, ... Gardner, TA. 2016. Anthropogenic disturbance in tropical forests can double biodiversity loss from deforestation. Nature. 535, 144-147. https://doi.org/10.1038/nature18326 
Basiron Y. 2007. Palm oil production through sustainable plantations. European Journal of Lip Scien T, 109(4), 289-295.

Benami E, Curran LM, Cochrane M, Venturieri A, Franco R, Kneipp J, Swartos A. 2018. Oil palm land conversion in Pará, Brazil, from 2006-2014: evaluating the 2010 Brazilian Sustainable Palm Oil Production Program. Environmental Research Letters. 13(3):034037.

Berenguer E, Ferreira J, Gardner TA, Aragão LEOC, Camargo PB, Cerri CE, Durigan M, Oliveira Junior RC, Vieira, ICG, Barlow J. 2014. A large-scale field assessment of carbon stocks in humanmodified tropical forests. Global Change Biology. 20(12):3713-3726.

BRASIL. 2010. Decreto Federal no 7.172/2010. Brasília (DF). [accessed 2013 Oct 21]. http://www.planalto.gov.br/ccivil_03/_Ato2007-2010/

Bremer B, Bremer K, Chase M, Fay M, Reveal J, Soltis D, Soltis P, Stevens P. 2009. An update of the Angiosperm Phylogeny Group classification for the orders and families of flowering plants: APG III. Botanical Journal of the Linnean Society. 161(2):105-121. doi:10.1111/j.1095-8339.2009.00996.x

Butler RA, Laurence FW. 2009. Is oil palm the next threat to the Amazon? Tropical Conservation Science. 2(1):1-10.

Chave J, Andalo C, Brown S, Cairns MA, Chambers JQ, Eamus D, Folster H, Fromard F, Higuchi N, ... Kira T. 2005. Tree allometry and improved estimation of carbon stocks and balance in tropical forests. Oecologia. 145:87-99.

Chave J, Coomes DA, Jansen S, Lewis SL, Swenson NG, Zanne AE. 2009. Towards a worldwide wood economics spectrum. Ecology Letters 12(4):351-366. doi:10.1111/j.1461-0248.2009.01285.x

Chazdon RL, Peres CA, Dent D, Sheil D, Lugo AE, Lamb D, Stork NE, Miller SE. 2009. The potential for species conservation in tropical secondary forests. Conservatio on Biology. 23:106-1417.

Chao, A., Chazdon, RL, Colwell, RK, \& Shen, TJ. 2005. A new statistical approach for assessing similarity of species composition with incidence and bundance data. Ecol Lett. 8(2), 148-159.

CIENTEC. 2006. Software Mata Nativa 2.06: Sistema para análise fitossociológica, elaboração de inventários e planos de manejo de florestas nativas. Viçosa (MG): Cientec.

Corley RHV, Tinker PB. 2003. The oil palm. Fourth edition. Oxford (UK): Blackwell Science Limited.

Colwell RK, Mao CX, Chang J. 2004. Interpolating, extrapolating, and comparing incidence-based species accumulation curves. Ecology. 85:2717-2727.

Colwell RK, Chao A, Gotelli NJ, Lin SY, Mao CX, Chazdon RL, Longino, JT. 2012. Models and estimators linking individual-based and sample-based rarefaction, extrapolation and comparison of assemblages. Journal of Plant Ecology, 5(1), 3-21.Corley RHV, Tinker PB. 2003. The oil palm. Fourth edition. Oxford (UK): Bla. Scie. L.

Cottam, G, Curtis, JT. (1956). The Use of Distance Measurements in Phytosociological Sampling. Ecology, 37, 451-460

Cunha EJ, Assis Montag LF, Juen L. 2015. Oil palm crops effects on environmental integrity of Amazonian streams and Heteropteran (Hemiptera) species diversity. Ecol. Indic. 52:422-429.

[EMBRAPA] Empresa Brasileira de Pesquisa Agropecuária. 2009. Sistema brasileiro de classificação de solos. Centro Nacional de Pesquisa de Solos (Brasil). Brasília (DF): Serviço de Produção de Informação.

Ferreira J, Lennox GD, Gardner TA, Thomson JR, Berenguer E, Lees AC, Mac Nally R, Aragão LE, Ferraz SF, Louzada J, Moura NG. 2018. Carbon-focused conservation may fail to protect the most biodiverse tropical forests. Nature Climate Change, 8(8), 744.

Filho DC. 2012. Crescimento e estoque de carbono no dendeizeiro hibrido interespecífico BRS Manicoré em função da idade no Nordeste Paraense Amazônia oriental [dissertation]. Belém (PA): Universidade Rural da Amazônia.

Fitzherbert EB, Struebig MJ, Morel A, Danielsen F, Brühl CA, Donald PF, Phalan B. 2008. How will oil palm expansion affect biodiversity?. Trends in Ecology \& Evolution, 23(10), 538-545. 
Freitas, FL, Sparovek, G, Berndes, G, Persson, UM, Englund, O, Barretto, A, Mörtberg, U. 2018. Potential increase of legal deforestation in Brazilian Amazon after Forest Act revision. Nature Sustainability, 1(11), pp.665.

Gardner TA, Ferreira J, Barlow J, Lees AC, Parry L, Vieira ICG, Berenguer E, Abramovay R, Aleixo A, Andretti C, ... Aragão LE. 2013. A social and ecological assessment of tropical land uses at multiple scales: the Sustainable Amazon Network. Phil. Trans. R. Soc. B. 368: 20120166. doi:10.1098/rstb. 2012.0166.

Gilroy JJ, Prescott GW, Cardenas JS, Castañeda PGDP, Sánchez A, Rojas-Murcia LE, Medina Uribe CA, Haugaasen T, Edwards DP, 2015. Minimizing the biodiversity impact of Neotropical oil palm development. Global change biology, 21(4), pp.1531-1540.

Homma O, Furlan Júnior J, Carvalho RA, Ferreira CAP. 2000. Bases para uma política de desenvolvimento da cultura do dendezeiro na Amazônia. In: Viégas IJM, Müller AA, editors. A Cultura do dendezeiro na Amazônia brasileira. Belém (PA): Embrapa Amazônia Oriental/Embrapa Amazônia Ocidental. 11-30.

IBGE. 2010. Brasil: Instituto Brasileiro de Geografia e Estatística. [accessed 2015 Dec 13]. http://www.ibge.gov.br/cidadesat/.

Koh LP, Wilcove DS. 2008. Is oil palm agriculture really destroying tropical biodiversity?. Conserv. Lett. $1: 60-64$.

Lees AC, Peres CA. 2006. Rapid avifaunal collapse along the Amazonian deforestation frontier. Biol. Conserv. 133:198-211. doi:10.1016/j.biocon.2006.06.005.

Lees AC, Vieira ICG. 2013. Forests: Oil-palm concerns in Brazilian Amazon. Nature. 497:188-188.

Lees AC, Moura NG, Almeida AS, Vieira ICG. 2015. Poor prospects for avian biodiversity in Amazonian oil palm. PloS one. 10 (5): e0122432.

Mendes-Oliveira AC, Peres CA, Maués PCRDA, Oliveira GL, Mineiro IG, de Maria SLS, Lima, RC. 2017. Oil palm monoculture induces drastic erosion of an Amazonian forest mammal fauna. PloS one, 12(11), e0187650. doi:10.1371/journal.pone.0187650

Moni M, Sulaiman SA. 2013. Downdraft gasification of oil palm frond: effects of temperature and operation time. Asian J of Sci Res. 6:197-206.

Morel AC, Saatchi SS, Malhi Y, Berry NJ, Banin L, Burslem D, Nilus R, ... Ong RC. 2011. Estimating aboveground biomass in forest and oil palm plantation in Sabah, Malaysian Borneo using ALOS PALSAR data. Forest Ecology and Management. 262 (9), 1786-1798

Moura NG, Lees AC, Aleixo A, Barlow J, Dantas SM, Ferreira J, Lima MFC, Gardner TA. 2014. Two hundred years of local avian extinctions in Eastern Amazonia. Conserv. Biol. 28:1271-1281.

Nelson BW, Mesquita R, Pereira JL, Souza SGA, Batista GT, Couto LB. 1999. Allometric regressions for improved estimate of secondary forest biomass in the central Amazon. Forest Ecol. and Manag. 117(1-3):149-167.

Oksanen J, Blanchet FG, Kindt R, Legendre P, O'Hara RB, Simpson GL, Solymos P,. Stevens MHH, Wagner H, Friendly M, McGlinn D, Minchin PR, Szoecs E. 2019. vegan: Community Ecology Package. $R$ package version 2.5-4. https://CRAN.R-project.org/package=vegan

Peres CA, Gardner TA, Barlow J, Zuanon J, Michalski F, Lees AC, Vieira ICG, Moreira FMS, and Feeley KJ. 2010. Biodiversity conservation in human-modified Amazonian forest landscapes. Biological Conservation 143: 2314-2327.

Pirker J, Mosnier A, Kraxner F, Havlík P, Obersteiner M. 2016. What are the limits to oil palm expansion? Glob. Environ. Change. 40:73-81.

Poorter L, Bongers F, Aide TM, Zambrano AMA, Balvanera P, Becknell JM, Boukili V, Brancalion PH, Broadbent EN, Chazdon RL, Craven D. 2016. Biomass resilience of Neotropical secondary forests. Nature. 530(7589):211-214.

Putz FE, and Redford $\mathrm{KH}, 2010$. The importance of defining 'forest': Tropical forest degradation, deforestation, long-term phase shifts, and further transitions. Biotropica, 42(1), 10-20. 
Team RC. (2019). R: A language and environment for statistical computing. R Foundation for Statistical Computing, Vienna, Austria. https://www.R-project.org/.

Ter Steege H, Sabatier D, Castellanos H, Van Andel T, Duivenvoorden J, De Oliveira AA, Ek R, Lilwah R, Maas P, Mori S. (2000). An analysis of the floristic composition and diversity of Amazonian forests including those of the Guiana Shield. Journal of Tropical Ecology, 16(6), 801-828.

Reis EJ, Guzmán RM. 2015. An econometric model of Amazon deforestation. Brasília: Rio de Janeiro: Instituto de Pesquisa Econômica Aplicada - IPEA. Discussion papers 0034.

Tan KT, Lee KT, Mohamed AR, Bhatia S. 2009. Palm oil: addressing issues and towards sustainable development. Renewable and sustainable energy reviews, 13(2), 420-427.

Vieira ICG 2019. land use drives change in amazonian tree species. An Acad Bras Cienc 91: e20190186. DOI 10.1590/0001-3765201920190186.

Vieira ICG, de Almeida AS, Davidson EA, Stone TA, de Carvalho CJR, Guerrero, JB. 2003. Classifying successional forests using Landsat spectral properties and ecological characteristics in eastern Amazonia. Remote Sensing of Environment, 87(4), 470-481.

Vieira ICG, Gardner T, Ferreira J, Lees AC, Barlow J. 2014. Challenges of governing second-growth forests: A case study from the Brazilian Amazonian State of Pará. Forests. 7(5):1737-1752.

Yusoff S. 2006. Renewable energy from palm oil-innovation on effective utilization of waste. Journal of cleaner production, 14(1), 87-93.

Zanne AE, Coomes D, Jansen S, Lewis SL, Swenson NG, Chave J. 2009. Towards a worldwide wood economics spectrum. Ecology letters, 12(4), 351-366. https://doi.org/10.1111/j.14610248.2009.01285.x

\section{Author information}

\section{Arlete S. de Almeida}

Arlete S. de Almeida works on environmental science and landscape ecology.

\section{Ima C. G. Vieira}

Ima C. G. Vieira works on forest ecology and restoration and is interested to improve the interface between science and policy.

\section{Nárgila Moura}

Nárgila Moura works on the ecology and conservation of tropical biodiversity.

\section{Alexander C. Lees}

Alexander C. Lees works on biodiversity conservation globally and is especially interested in conservation-development trade-offs.

\section{Funding}

The work has been funded by the Conselho Nacional de Desenvolvimento Científico e Tecnológico (CNPq), within the network INCT/Biodiversidade e Uso da Terra na Amazônia [CNPq no 574008/2008-0]. 